\title{
Dendrochronological Investigations of Valonia Oak Trees in Western Greece
}

\author{
Andreas Papadopoulos ${ }^{1 *}$, Anastasia Pantera ${ }^{1}$
}

(1) Technological Educational Institute Stereas Elladas, Department of Forestry and Natural Environment Management, Demokratias 3, GR-36100 Karpenissi, Greece

* Correspondence: e-mail: ampapadopoulos@teiste.gr
Citation: PAPADOPOULOS A, PANTERA A 2016 Dendrochronological Investigations of Valonia Oak Trees in Western Greece. South-east Eur for 7 (1): 29-37. DOI: http:// dx.doi.org/10.15177/seefor.16-05

Received: 3 Nov 2015; Revised: 19 Dec 2015, 25 Jan 2016; Accepted: 27 Jan 2016; Published online: 11 Mar 2016

\begin{abstract}
Background and Purpose: Valonia oak (Quercus ithaburensis subsp. macrolepis (Kotschy) Hedge \& Yalt.) is an east Mediterranean endemic, xerothermic and deciduous tree of particular interest in forestry. There has been a growing demand lately to include the species in reforestations in Greece which also increased the interest to investigate its response to climate change. The main purpose of this research is to study valonia oak from a dendrochronological dendroclimatological point of view within its Mediterranean distribution range.

Materials and Methods: Sampling took place in characteristic valonia oak stands where cross sections or treecores were taken from 40 trees. The cross sections and the tree-cores were prepared and cross-dated using standard dendrochronological methods and tree-ring widths were measured to the nearest $0.001 \mathrm{~mm}$ using the Windendro software program. The ARSTAN program was used to standardize the tree-ring data and to calculate dendrochronological statistical parameters. The inter-annual variability of tree-ring width and the radial growth trend were examined. Finally, tree-ring widths to climate relationships were calculated by orthogonal regression in combination with the bootstrap procedure using master residual chronology and monthly precipitation, temperature data and scPDSI drought index, from October of the $n-1$ year up to November of the $n$ year.

Results: The master chronology of valonia oak trees in Western Greece reaches 365 years, with an average ring width of $0.89 \mathrm{~mm}$ and with mean sensitivity being 0.21 . The variation of the tree-ring widths indicates the influence of climate and human intervention in the past. Tree-ring to climate relationships show that valonia oak growth is positively affected by precipitations in January and March and by drought reduction during June and July.

Conclusions: Valonia oak in Western Greece is a species of great interest for dendrochronological and dendroclimatological studies due to the old age of the trees and the species response to climate variation. The climate factors that mostly affect its growth are winter and spring precipitation and summer drought.
\end{abstract}

Keywords: dendrochronology, dendroclimatology, tree-ring, Quercus ithaburensis subsp. macrolepis, old trees, east Mediterranean

\section{INTRODUCTION}

Quercus ithaburensis is an east Mediterranean endemic, deciduous oak tree species, present as two subspecies: a) Q. ithaburensis (Kotschy) Hedge \& Yaltirik subsp. ithaburensis (tabor oak), found mostly in Anatolia and the Middle East, and b) Q. ithaburensis subsp. macrolepis (Kotschy) Hedge \& Yaltirik (valonia oak), found mostly in South-East Italy, Albania, Greece, and west Anatolia [1-4].
In Greece, valonia oak covers an area of 29,631.80 ha in lowlands and uplands of continental and insular territory, usually in the form of open forests managed as traditional silvopastoral system $[4,5]$. From the $17^{\text {th }}$ to $19^{\text {th }}$ century these forests highly contributed to the local economy by dye production extracted from the acorn cups, the production of wood for shipbuilding and their usage as silvopastures $[4,6]$. During the $20^{\text {th }}$ century many of these forests were cleared and converted to agricultural fields 
or rural establishments, while the remaining ones were left to natural succession that resulted in the formation of old-aged oak stands. Nowadays their importance is mainly of an ecological basis, while there is also an increasing economic interest in them, reviving their traditional uses including silvopastoralism [7].

This species is one of the few deciduous oak species thriving in the Mediterranean xerothermic conditions [8, 9], which makes it an interesting option for reforestation in Greece and other Mediterranean countries. Indeed, the anticipated climate change effects on the growth, productivity and present distribution of the Mediterranean vegetation $[10,11]$, renders necessary the quest of species that would easily adapt to the new conditions and the investigation of their behaviour. Based on a study about the impact of climate change in Greece [12], the expected temperature increase and precipitation decrease will result in the expansion of heat tolerant forest plant species by $2-4 \%$ and desertification by $1-2 \%$, depending on the climate change scenario. Valonia oak with its ability to grow in xerothermic environments, even within phrygana [5], could be one of the recommended species for the future, being less flammable than xerothermic conifers and easily regenerating after a forest fire [4].

In this context, the exploration of valonia oak treering width variability and its climate-growth relationships that can be examined through dendrochronological studies is essential for predicting its future growth trend. The long time series of tree-ring width measurements can substantially contribute to this study. Radial growth combines the effects of climate, site-specific factors, and natural and human disturbances [13-15]. There are many large deciduous oak trees throughout Greece and some are particularly close to historical sites. However, only few of the Greek deciduous oaks species have been used to construct tree-ring chronologies from samplings carried out on living trees [16] and mostly from wood of historical monuments $[17,18]$. Concerning valonia oak, there have been few dendrochronological studies in Greece and the Mediterranean region $[19,20]$. The objectives of this study were the construction of a local tree-ring width chronology of this species in Western Greece and the investigation of tree-rings to climate relationships.

\section{MATERIALS AND METHODS}

Sampled trees were growing in Xeromero, a typical valonia oak forest of the Aetoloakarnania prefecture, Western Greece (Figure 1). It is an old forest with rich fauna and flora [21] and old-age stands that have not been harvested for centuries. It is the largest forest of valonia oak in the Balkans and probably one of the largest within its distribution area in the Mediterranean basin. This forest had particular value in the past due to the superior quality of the acorns produced, compared to others from similar Greek forests in terms of tannin content and its grazingpasture use and value [22]. Within this area, valonia oak usually forms stands of open canopy, growing on shallow calcareous soils at an altitude ranging from 0 to $580 \mathrm{~m}$ a.s.l.
Based on the Agrinion Meteorological Station, located 20 kilometres from the sampling site, for the period of 19562012 (Hellenic National Meteorological Service), the mean annual precipitation in the region is $938.5 \mathrm{~mm}$ and the mean annual temperature is $16.8^{\circ} \mathrm{C}$. The drought period, based on the ombrothermic diagram [23], lasts for 3.5 months from late May to early September.

Forty trees were sampled based on dendrochronological criteria $[13,15]$, from an area of approximately 5 ha representative of the valonia oak stands characteristics and with homogeneous topography (Figure 1). The sampling included cross sections that were taken at breast height $(1.3 \mathrm{~m})$ from 20 trees during previous loggings and 20 tree cores that were extracted, also at breast height, from the remaining ones. Tree diameters at breast height ranged from 27.7 to $98.1 \mathrm{~cm}$. It should be noted that trees of diameter at breast height over $25 \mathrm{~cm}$ were not easy to be found in the area. The tree-ring cores were extracted using Pressler's increment borers of 40 and $60 \mathrm{~cm}$ long, with special care to avoid ramifications and irregular wood structure, as much as possible. The trees crosssections and cores were dried, planed and sanded with progressively finer grades of sandpaper (80, 100, 200, 400 and 600 grit) until the tree-rings were distinguishable under a stereomicroscope.

Radial increments and selected radial directions of cross sections were measured to the nearest 0.001 $\mathrm{mm}$ by Windendro program [24] and cross-dated using a stereoscope, pointer years [15], skeleton plotting and other methods [25-27]. The cross-dating was statistically checked in the course of tree-ring width measurements with Windendro. To remove the low-frequency variation in the elementary tree-ring series and to quantify the tree-ring to climate relationships, index chronologies were constructed using ARSTAN program [28]. A double detrending procedure was done, first by using a negative exponential or linear regression and then by using a cubic smoothing spline function preserving $50 \%$ of variance at wavelength of 30 years. Tree-ring widths were converted into indices by dividing observed values with expected values derived from the above-mentioned detrending line. In these indices, the remaining first-order temporal autocorrelation was removed by autoregressive modelling [28]. Finally, the produced individual residual series were then averaged using a bi-weighted robust mean to obtain the master residual chronology. Standard dendrochronological statistical parameters [13] were calculated for the master raw tree-ring chronology and for three age classes (a group of young trees of ages between 100 and 200 years; the middle group of ages between 200 and 300 years, and an old-tree group of trees older than 300 years): mean tree-ring width, standard deviation (Std), mean sensitivity and first-order autocorrelation coefficient. Additionally, the EPS statistic [29] was computed on the dataset after detrending in ARSTAN. The mean rawchronologies for the above mentioned age-classes were used for the visualization of the growth trend, while the master residual chronology was used to identify the very narrow and wide characteristic tree-rings (greater than 3 Std of the mean value). 


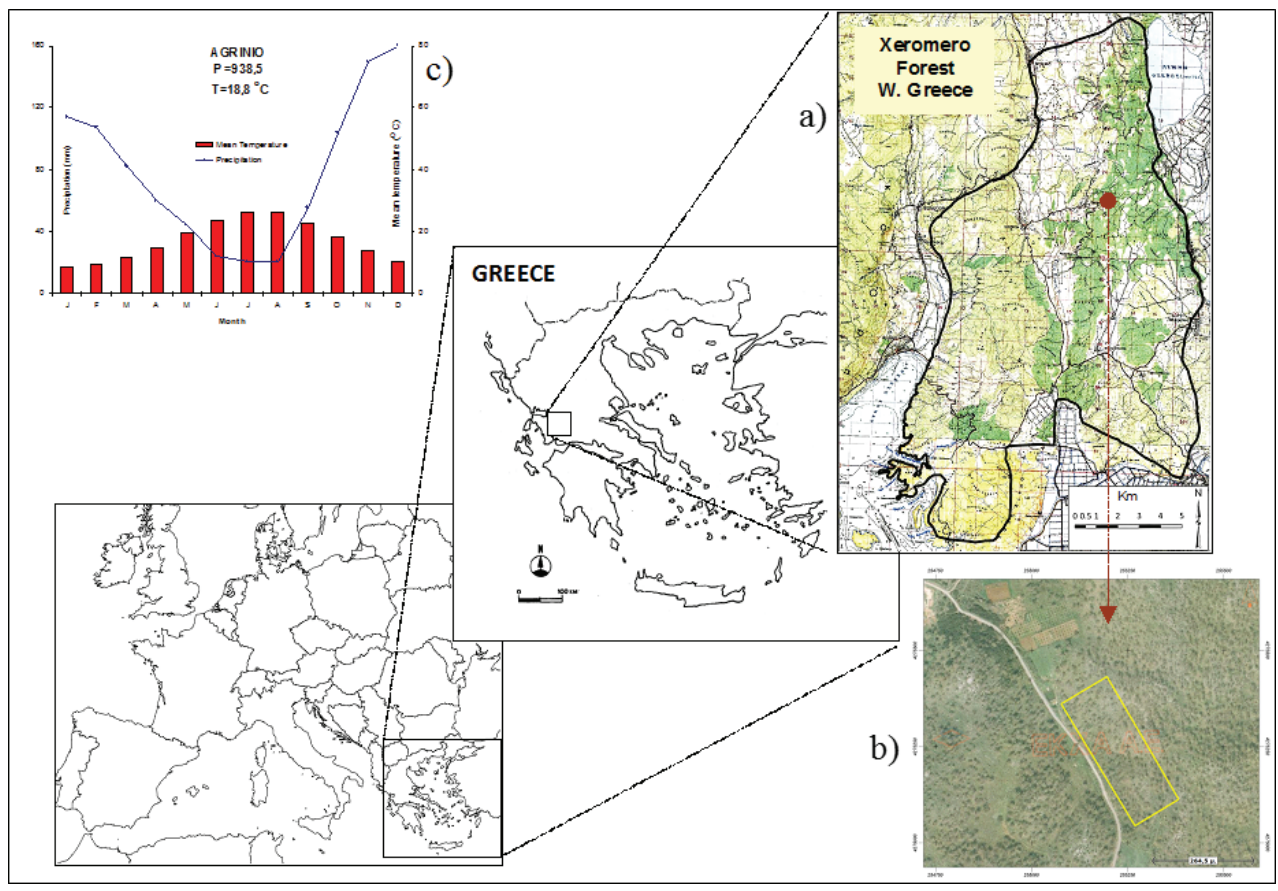

FIGURE 1. (a) Map of the Xeromero forest, (b) satellite image of sampling site (www.ktimatologio.gr) and (c) the ombrothermic diagram of the nearest meteorological station of Agrinio (24 m a.s.l.) for the period from 1956 to 2012.

Climate-growth relationships were calculated for the period of 1981-2013 by orthogonal regression in combination with the bootstrap procedure $[30,31]$ using the 3PBase software [32]. The independent variable of this regression was the master residual chronology of tree-ring widths, whereas the regressors were 28 monthly parameters (14 monthly precipitation in combination with 14 mean monthly temperatures: P-Tmean), or 14 monthly drought indices (self-calibrated Palmer Drought Severity Indices: scPDSI) from October of the preceding year to November of the current year. This period of 14 months was chosen taking into account that tree growth in the southern most Mediterranean regions may continue until November or even until the beginning of winter. As for scPDSI, according to Wells et al. [33], this index is calculated from precipitation and temperature data as well as from the available local soil water content and it varies from -4 (extreme drought) to +4 (extremely wet). The climatic data were obtained from the KNMI Climate Explorer [34, 35] due to the incomplete data from the local meteorological stations in the proximity of the study area. We used monthly precipitation and mean temperature data of the CRU TS3.22 [36] and monthly UCAR SCPDSI drought indices [37]. The closest grid point to the site studied was selected from each gridded data category. The results of the climate-growth relationships are presented as a ratio between the regression coefficient of each monthly climatic parameter and the associated standard deviation (mean of 50 simulations) [30].

\section{RESULTS}

\section{Cross-Dating and Tree-Ring Chronologies}

From the cross-dating procedure it derives that, due to the wood structure of valonia oak trees (in many cases tree-rings are very thin and not distinguishable, there is presence of discoloration and wood abnormal structure), cross-dating in the middle and old-age group is difficult (Figure 2). The difficulty degree increased with narrow tree-rings. For this reason, cross-dating was possible for 19 out of the 20 cross sections (rate $95 \%$ ) and 11 out of the 20 cores (rate $55 \%$ ).

Based on the total cross-dated elementary series, master chronology length was 365 years, mean tree-ring width was $0.89 \mathrm{~mm}$, standard deviation $0.31 \mathrm{~mm}$, mean sensitivity 0.21 and the first-order autocorrelation 0.67 (Table 1). The above mentioned statistics do not differ substantially if calculated separately for each tree age class of 100 years. Tree-ring width in the three age classes tested ranged from 0.86 to $0.90 \mathrm{~mm}$ (std $0.28 \mathrm{~mm}$ ), mean sensitivity from 0.19 to 0.21 and first-order autocorrelation from 0.60 to 0.67 (Table 1). The EPS value for the common period of the series (1815-2010) was 0.68 and exceeded the threshold value of 0.85 [29] in the year 1981 .

From the graphical representation of the tree-ring raw mean chronologies and the 20 years mean moving average for each age class (Figure 3), an intense appearance of low frequency variation has been observed throughout the period without noticing any periodicity. The examination of 
TABLE 1. Descriptive statistics of valonia oak tree-ring width raw data, for all trees and for the three age classes.

\begin{tabular}{|c|c|c|c|c|}
\hline Tree age & Total & $100-200$ & $200-300$ & $>300$ \\
\hline Number of trees & 30 & 7 & 20 & 3 \\
\hline Period A.D. & $1650-2014$ & $1815-2013$ & $1718-2014$ & $1650-2010$ \\
\hline Chronology length (years) & 365 & 199 & 297 & 361 \\
\hline Mean ring width (mm) & 0.89 & 0.90 & 0.93 & 0.86 \\
\hline Standard deviation & 0.31 & 0.28 & 0.28 & 0.28 \\
\hline Mean sensitivity & 0.21 & 0.19 & 0.21 & 0.21 \\
\hline First-order autocorrelation & 0.67 & 0.67 & 0.67 & 0.60 \\
\hline
\end{tabular}

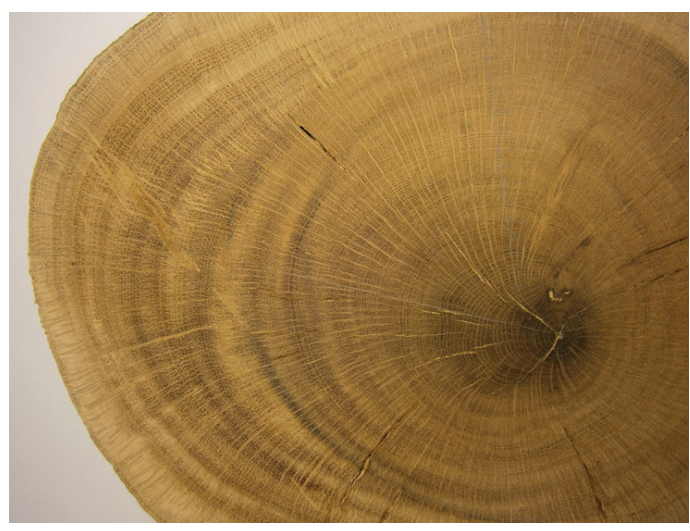

FIGURE 2. Cross section of a valonia oak tree from the study area.

the tree-rings growth trend indicated a growth reduction from the beginning of the chronologies until the period of 1880-1900. Then, an increase trend was observed which was, however, halted in the period of 1990-2000 with a tendency to revert afterwards. Focusing on the master residual chronology (Figure 4), it shows a more intense inter-annual variation in the period of 1650-1745 compared to the following period with the exception of the years 1990 and 2000 when particularly narrow tree rings were observed. Characteristic narrow tree-rings were also observed in the years 1661 and 1715 , with particularly wide rings appearing in the years 1660, 1687 and 1718 . Many of these years were used in cross-dating as pointer years.

\section{Tree-Rings to Climate Relationships}

Statistically significant $(p<0.05)$ positive correlations were calculated between tree-ring width and January and March precipitation (Figure 5). No significant correlations were found between tree-ring widths and mean temperature of any month. Regarding the scPDSI drought index, a positive significant correlation $(p<0.05)$ appeared in June and July (Figure 6).

\section{DISCUSSION}

This dendochronological study of valonia oak trees created a new master chronology for the time period of 1650-2014 that may contribute to the densification of the dendrochronological network in South-East Europe [18, 3841]. It may be used in comparison with new chronologies of the species but also with other oak species. Furthermore, it may contribute to climate reconstruction studies that have been the subject of several researches in the eastern Mediterranean region who used long tree-ring time-series [42-48]. At this stage, due to low EPS value found before 1981, the constructed chronology needs to be upgraded with more elementary chronologies from new cores or cross sections.

Regarding the ages of valonia oak trees it appears that the observed forest is composed of uneven-aged stands, although they seemingly resemble to be even-aged. This impression is given because of the single-layer structure of the forest, the open canopy cover and the lack of lower diameter class trees. The presence of old-age trees in the study site and the region in general [20] indicates that these stands have evolved after the French-Hellenic exploitation of Western Greece forests in the $17^{\text {th }}$ century [6], a period during which many large-diameter trees were harvested to produce shipbuilding timber. After this period, according to data from the local Forest Service, there has not been any systematic logging and the stands were only used for the production of acorn cups for tannin production collected mainly from large, sparsely scattered trees. These old-age trees are nowadays reserved mainly for ecological purposes.

The small tree-ring widths, on average did not exceed $1 \mathrm{~mm}$ (Table 1) and did not show any significant decreasing trend with age, is a species-specific characteristic which is slow-growing and usually developing on shallow, degraded calcareous soils. Mean sensitivity (mean value 0.21 ) is relatively high compared to the Greek coniferous species [49] and is almost proportional to the values of Aleppo pine in the sub-humid bioclimate type [50], whereas it is higher than the mean sensitivity of other deciduous Greek oak species [16]. The relatively high mean sensitivity values found suggest a significant climatic signal, as reflected by valonia 

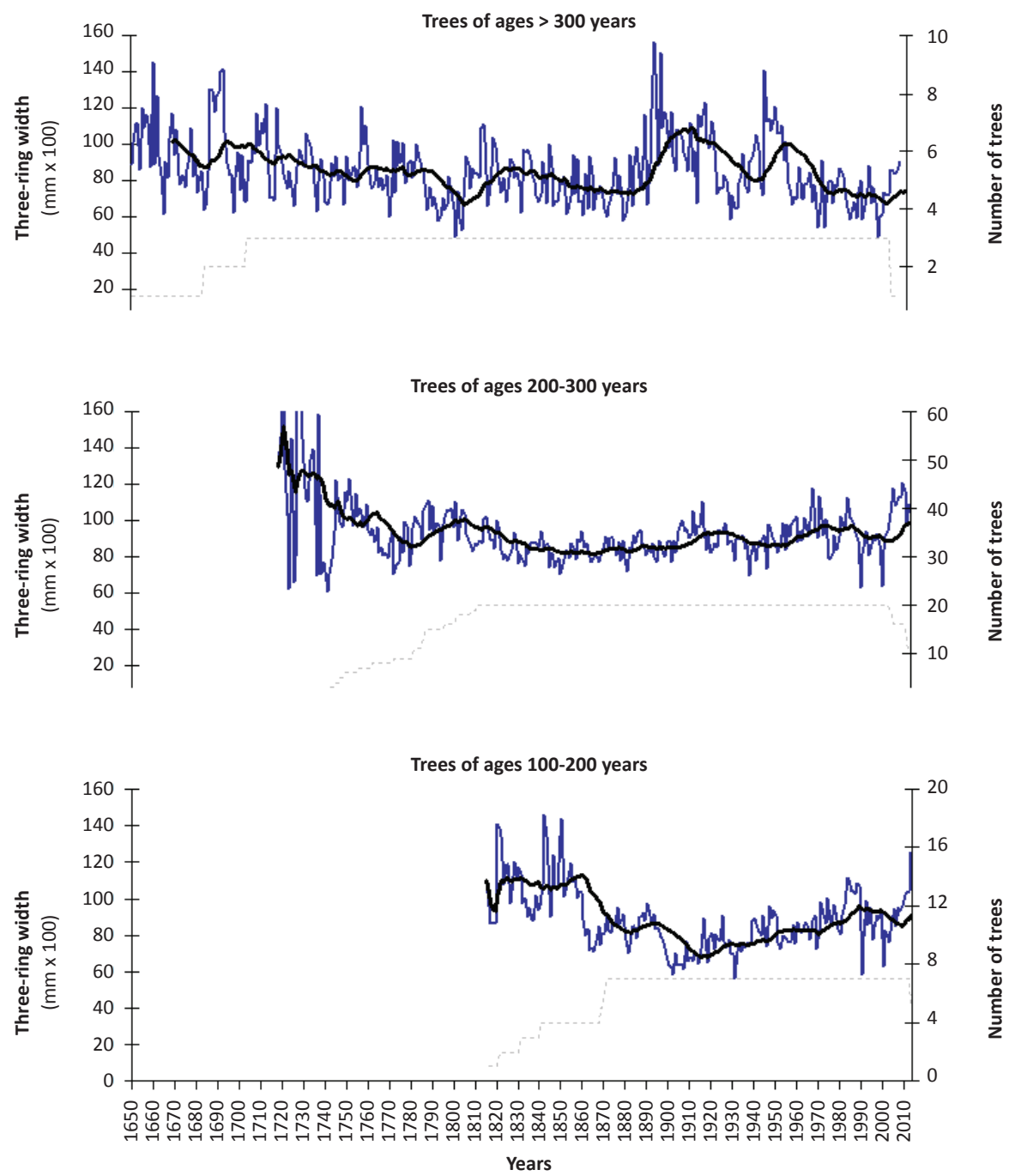

FIGURE 3. Tree-ring width mean chronologies for three age classes; the bold line superimposed indicates the mean moving average of 20 years and the dashed line shows the number of samples used in each chronology.

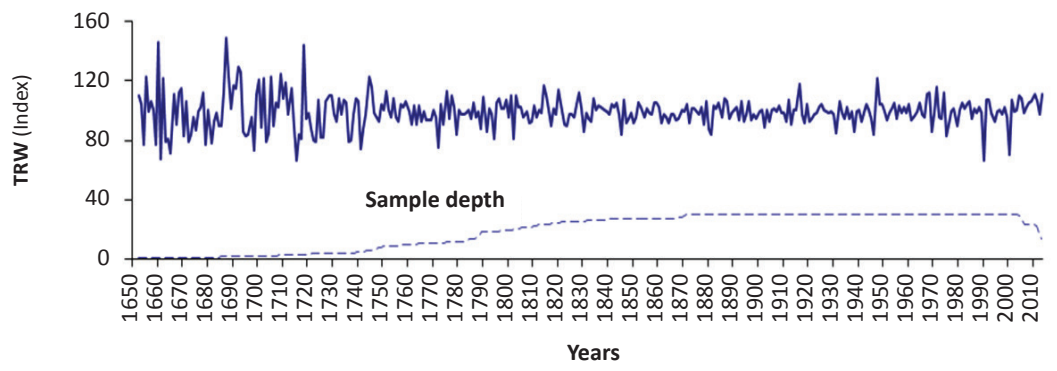

FIGURE 4. Master residual chronology of tree-ring widths (TRW); the dashed line shows the number of samples used in the chronology. 


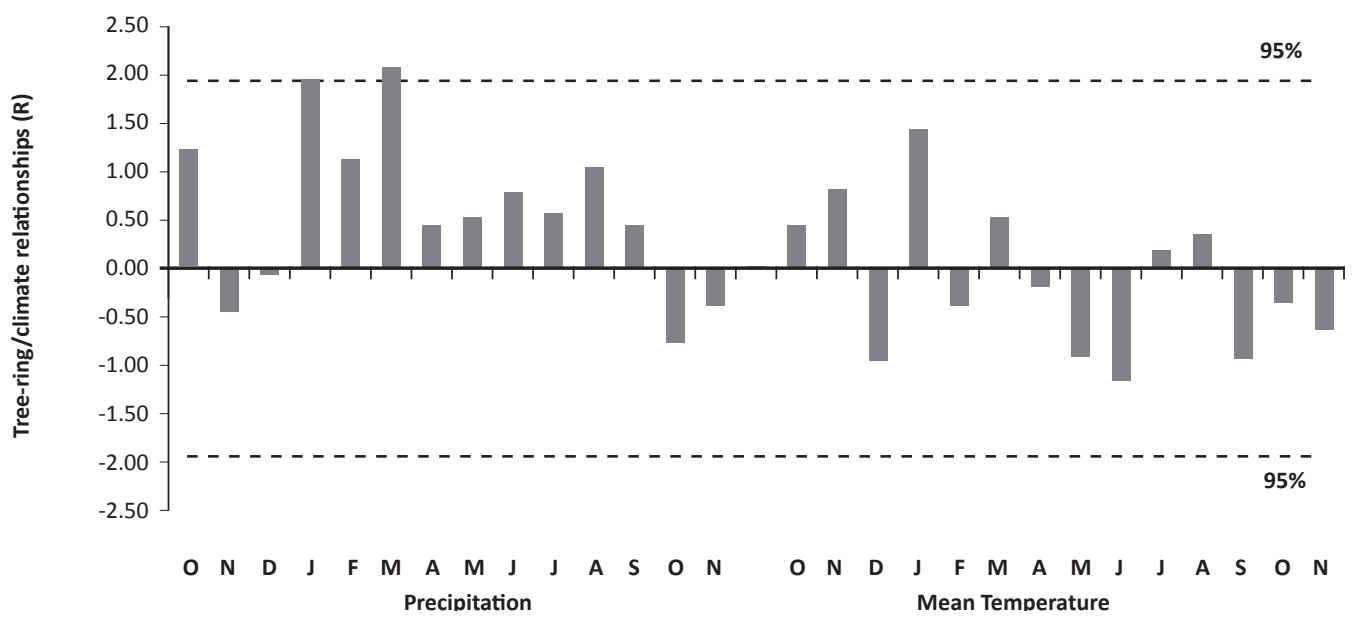

FIGURE 5. Tree-ring to climate relationships calculated between master residual chronology and 28 climatic parameters (monthly precipitation and mean monthly temperature) for the period of 1981-2013. Dashed horizontal lines indicate $95 \%$ significance level, $R=r / s, r=$ mean regression coefficient, $s=$ mean standard deviation (for 50 simulations).

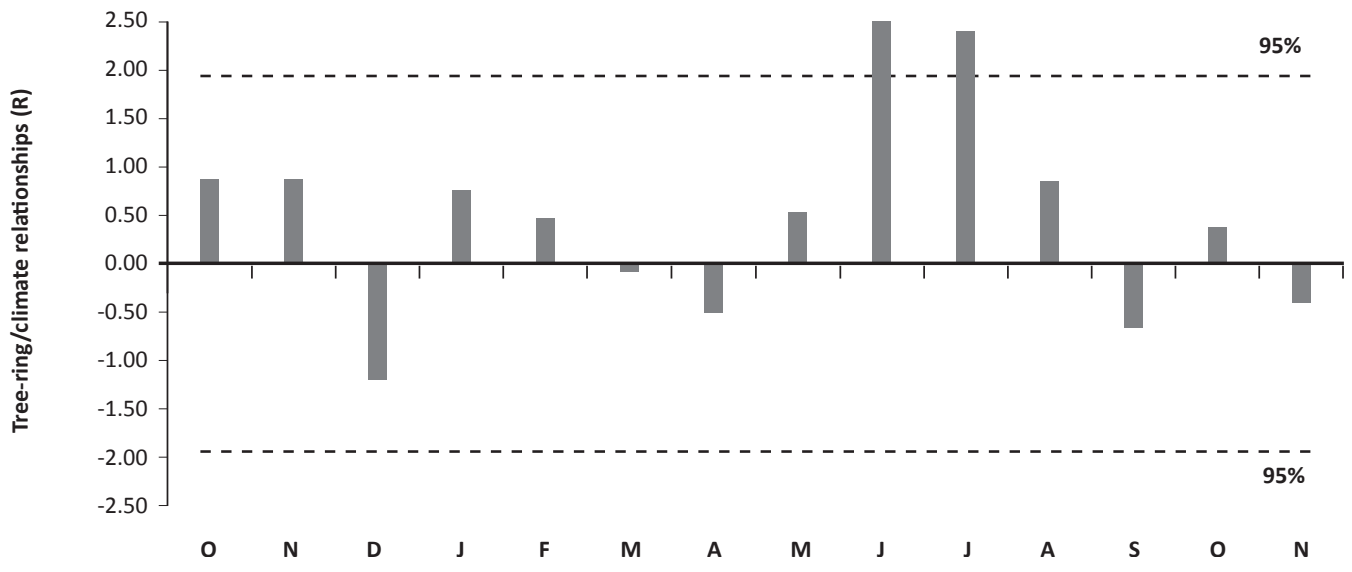

FIGURE 6. Tree-ring to climate relationships calculated between master residual chronology and 14 climatic indices (monthly SCPDSI) for the period of 1981-2013. Dashed horizontal lines indicate $95 \%$ significance level, $R=r / s, r=m e a n$ regression coefficient, $\mathrm{s}=$ mean standard deviation (for 50 simulations).

oak tree-rings, and are indicative of the appropriateness of the species to be used in dendrochronological studies. The high first-order autocorrelation indicates a low frequency variation in the tree-ring chronologies, revealing the residual action of certain site factors during the formation of successive tree-rings [13]. This variation can be interpreted mainly by the effects of anthropogenic factors that have affected those forests in the past, such as pruning for higher acorn production and grazing, and the influence of different environmental factors such as climate. The analysis of the low and high frequency variation in the chronologies, in relation to other research or historical data, enhances the hypothesis of climate effect. For example, the last decade of the $20^{\text {th }}$ century is a period of a decreasing tendency in tree-ring width, noted and characterized as dry and warm for Greece and East Mediterranean [51, 52]. Furthermore, the year 1715 , with the distinctive narrow tree-rings, was marked with long dry periods and was characterised as a year of great famine, especially for the central and southern Greece [53]. 
Concerning tree-rings to climate relationships, January precipitation that precedes the tree-ring formation phase as well as March precipitation coinciding with the commencement of tree-ring growth, play a prevailing role in valonia oak tree-ring growth. The positive effect of winter precipitation could be attributed to water available in the soil for use during the tree-growing season. Moreover, spring precipitation could attribute to the increased water demands for various physiological processes such as the intense cambium reactivation and growth release after winter dormancy. For the same species in Jordan, Touchan and Hughes [19] showed a relatively high positive correlation between October and May precipitations. The positive correlation of tree-ring widths with June and July scPDSI drought index explains the positive effect of drought reduction during the tree-ring growth period. Climate to growth relationships calculated signify, in a way, the xerothermic character of valonia oak. The adaptability of the species to grow in xerothermic environments confirms the results of the previous research on its ecophysiological response to summer drought [54]. According to personal observations in south Greece, valonia oak in periods of very intense summer drought sheds its leaves and re-sprouts smaller new ones, in late summer or early autumn along with the first rains after drought.

\section{CONCLUSION}

Valonia oak in Western Greece is of particular dendrochronological-dendroclimatological interest due to the old age of the trees, but also due to its response to climate variations. Tree-ring widths to climate relationships analysed in this research help us to adequately decode the role of climate on the inter-annual growth variability of the species. Winter precipitation and drought during the summer period play a major role in the radial growth of valonia oak. The study of these relationships combined with the scenarios of climate change can be a guide for predicting valonia oak forests future growth, but also for the usability of the species in reforestation practices in the Mediterranean area. Nevertheless, this study contributes to the dendrochronological research and, generally, to the knowledge of the species autoecology.

\section{Acknowledgment}

This research has been co-financed by the European Union (European Social Fund - ESF) and Greek national funds through the Operational Program "Education and Lifelong Learning" of the National Strategic Reference Framework (NSRF) - Research Funding Program: ARCHIMEDES III. Investing in knowledge society through the European Social Fund, MIS 380360.

\section{REFERENCES}

1. QUÉZEL P, BARBERO M 1985 Carte de la végétation potentielle de la région méditerranéenne. Feuille No 1: Méditerranée orientale. S.N.R.S., Paris, France, $69 \mathrm{p}$

2. KAPLAN D, GUTMAN M 1999 Phenology of Quercus ithaburensis with emphasis on the effect of fire. Forest Ecol Manag 115 (1): 61-70. DOI: http://dx.doi.org/10.1016/ S0378-1127(98)00436-8

3. TUTIN TG, BURGES NA, CHATER AO, EDMONDSON JR, VALENTINE DH, WALTERS SM, WEBB DA 1993 Flora Europaea. Vol. 1, Second Edition, Cambridge University Press, Cambridge, UK, $581 \mathrm{p}$

4. PANTERA A 2001 Establishment of Quercus ithaburensis Decaisne ssp. macrolepis (Kotschy) Hedge \& Yaltirik) in competence with understory vegetation in sylvopastoral systems. PhD thesis, Aristotle University of Thessaloniki, Faculty of Forestry and Natural Environment, Thessaloniki, Greece, $143 \mathrm{p}$ (in Greek)

5. PANTERA A., PAPADOPOULOS A, FOTIADIS G., PAPANASTASIS VP 2008 Distribution and phytogeographical analysis of Quercus ithaburensis ssp. macrolepis in Greece. Ecologia Mediterranea 34: 73-82

6. GIANNAKOPOULOU E 2002 Valonia oak forests (17th-19th century): economical perspectives. In: Veltsistas Th, Pantera A, Papadopoulos AM, Tzoganis A, Kapotis G, Fasoulis Chr (eds) Valonia oak forests: the past, the present, and the future. Giahoudis Publishing, Thessaloniki, Greece, pp 67-96 (in Greek)

7. PANTERA A, PAPADOPOULOS A, MANTZANAS $K$, PAPANASTASIS V, FOTIADIS G, VRAHNAKIS M, ALIFRAGIS D, ISPIKOUDIS I, et al. 2015 The contribution of valonia oak silvopastoral systems in Western Greece to local development and the environment. In: Lekkas TD (ed) Proceedings of the 14th International Conference on Environmental Sciences and Technology, CEST-2015_00100, Rhodes, Greece, 3-5 September 2015
8. QUÉZEL P, BONIN G 1980 Les forêts feuillues du pourtour méditerranéen. Constitution, écologie, situation actuelle, perspective. Revue Forestière Française 32 (3): 253-268

9. PAPADOPOULOS AM, VELTSISTAS TH, PANTERA A 2002 The position of valonia oak in the Mediterranean ecosystems. In: Veltsistas Th, Pantera A, Papadopoulos AM, Tzoganis A, Kapotis G, Fasoulis Chr (eds) Valonia oak forests: the past, the present, and the future. Giahoudis Publishing, Thessaloniki Greece, pp 13-23 (in Greek)

10. DE DIOS VR, FISCHER C, COLINAS C 2007 Climate change effects on Mediterranean forest and preventive measures. New Forest 33 (1): 29-40. DOI: http://dx.doi.org/10.1007/ s11056-006-9011-x

11. IPCC 2007 Climate change 2007: the physical science basis. In: Solomon S, Qin D, Manning M, Chen Z, Marquis M, Averyt KB, Tignor M, Miller HL (eds) Contribution of Working Group I to the Fourth Assessment. Report of the Intergovernmental Panel on Climate Change. Cambridge University Press, Cambridge, United Kingdom/New York, NY, USA, $996 \mathrm{p}$

12. BANK OF GREECE 2011 The environmental, economic and social impacts of climate change in Greece, Climate Change Impacts Study. Committee Bank of Greece Printing Works, Athens, Greece, $470 \mathrm{p}$

13. FRITTS HC 1976 Tree-rings and climate. Academic Press, London, UK, $567 \mathrm{p}$

14. FRITTS HC, SWETNAM TW 1989 Dendroecology: a tool for evaluating variations in past and present forest environments. Ad Ecol Res 19: 111-189. DOI: http://dx.doi.org/10.1016/ S0065-2504(08)60158-0

15. SCHWEINGRUBER FH 1996 Tree Rings and Environment: Dendroecology. Birmensdorf, Swiss Federal Institute for Forest, Snow and Landscape Research. Haupt, Berne, Stuttgart, Vienna, $609 \mathrm{p}$ 
16. NOAA 2015 International Tree-Ring Data Bank. URL: https:// www.ncdc.noaa.gov/data-access/paleoclimatology-data/ datasets/tree-ring (15 December 2015)

17. KUNIHOLM PI, STRIKER CL 1983 Dendrochronological investigations in the Aegean and Neighboring regions 19771982. J Field Archaeol 10 (4): 411-420. DOI: http://dx.doi. org/10.1179/009346983791504165

18. KUNIHOLM PI, STRIKER CL 1987 Dendrochronological investigations in the Aegean and Neighboring regions 19831986. J Field Archaeol 14 (4): 385-398. DOI: http://dx.doi. org/10.1179/ifa.1987.14.4.385

19. TOUCHAN R, HUGHES MK 1999 Dendrochronology in Jordan. J Arid Environ 42 (4): 291-303. DOI: http://dx.doi. org/10.1006/jare.1999.0507

20. PAPADOPOULOS A, PANTERA A 2013 Dating and treerings analysis of valonia oak aged trees from the Xeromero forest of Aetoloakarnania prefecture In: Hellenic Forestry Association, Protection and management of Greek forests in a period of financial crisis and the challenge of natural silviculture. Proceedings of $12^{\text {th }}$ Panhellenic Forest Conference, Thessaloniki, Greece, 6-9 October 2013, pp 310317 (in Greek)

21. VLAMI B, ZOGARIS S, DIMOPOULOS P 2003 Xeromero valonia oak forest. Eco-touristic guide. Ministry of Environment Energy and Climate Change, $71 \mathrm{p}$ (in Greek)

22. GRISPOS P 1936 Greek Forest History. Publication 25 of the Forest Applications Service, Ministry of Nation. Econ., Agricultural Sector, Forest Division, Athens, Greece, $385 \mathrm{p} \mathrm{(in}$ Greek)

23. BANGOULS F, GAUSSEN H 1953 Saison séche et indice xérothermique. Bull So. Hist Nat Toulouse 33: 193-239

24. REGENT INSTRUMENTS CANADA INC 2007 WinDENDRO 2008a. for Tree-Ring Analysis. Québec, Canada, $132 \mathrm{p}$

25. YAMAGUCHI DK 1991 A simple method for cross-dating increment cores from living trees. Can J Forest Res 21 (3): 414-416. DOI: http://dx.doi.org/10.1139/x91-053

26. MAXWELL RS, WIXOM JA, HESSL AE 2011 A comparison of two techniques for measuring and crossdating tree rings. Dendrochronologia 29 (4): 237-243. DOI: http://dx.doi.org/ doi:10.1016/i.dendro.2010.12.002

27. STOKES MA, SMILEY TL 1968 An introduction to tree-ring dating, The University of Chicago Press, Chicago, USA. $73 p$

28. COOK ER 1985 A time series analysis approach to tree-ring standardization. PhD Dissertation, University of Arizona, Tucson, USA, $171 \mathrm{p}$

29. WIGLEY TML, BRIFFA KR, JONES PD 1984 On the average value of correlated time-series, with applications in dendroclimatology and hydrometeorology. J Clim Appl Meteorol 23 (2): 201-213. DOI: http://dx.doi. org/10.1175/1520-0450(1984)023<0201:OTAVOC>2.0.CO;2

30. GUIOT J 1990 Methods and programs of statistics for paleoclimatology and paleoecology. Quantification des changements climatiques: Méthodes et programmes, Monographie № 1 , INSU, PNEDC, La Seyne-sur-Mer, France, $253 p$

31. GUIOT J 1991 Research report, the bootstrapped response function. Tree-Ring Bull 51: 39-41

32. GUIOT J, GOEURY C 1996 PPPBase, a software for statistical analysis of paleoecological and paleoclimatological data. Dendrochronologia 14: 295-300

33. WELLS N, GODDARD S, HAYES MS 2004 A self-calibrating Palmer Drought Severity Index. J Climate 17 (12): 2335-2351. DOI: http://dx.doi.org/10.1175/15200442(2004)017<2335:ASPDSI>2.0.CO;2

34. VAN OLDENBORGH GJ, BURGERS G 2005 searching for decadal variations in ENSO precipitation teleconnections. Geophys Res Lett 32 (15): L15701. DOI: http://dx.doi. org/10.1029/2005GL023110

35. TROUET V, VAN OLBENBORGH GJ 2013 Research tools. KNMI climate explorer: a web-based research tool for highresolution paleoclimatology. Tree-Ring Res 69 (1): 3-13. DOI: http://dx.doi.org/10.3959/1536-1098-69.1.3
36. HARRIS I, JONES PD 2014 CRU TS3.22: Climatic Research Unit (CRU) Time-Series (TS) Version 3.22 of High Resolution Gridded Data of Month-by-month Variation in Climate (Jan. 1901- Dec. 2013). NCAS British Atmospheric Data Centre, 24 September 2014. DOI: http://dx.doi.org/10.5285/18BE23F8D252-482D-8AF9-5D6A2D40990C

37. DAI A, TRENBERTH KE, QIAN T 2004 A global data set of Palmer Drought Severity Index for 1870-2002: Relationship with soil moisture and effects of surface warming. J Hydrometeorol 5 (6): 1117-1130 DOI: http://dx.doi.org/10.1175/JHM-386.1

38. GRIGGS CB, KUNIHOLM PI, NEWTON MW, WATKINS J, MANNING SW 2009 A 924-year regional oak tree-ring chronology for North-Central Turkey. In: Manning SW, Bruce MJ (eds) Tree-Rings, Kings and Old World Archaeology and Environment: Papers Presented in Honor of Peter lan Kuniholm. Oxbow Books, Oxford, UK, pp 71-80

39. TOUCHAN R, ANCHUKAITIS KJ, SHISHOV VV, SIVRIKAYA F, ATTIEH J, KETMEN M, STEPHAN J, MITSOPOULOS I, et al. 2014 Spatial patterns of Eastern Mediterranean climate influence on tree growth. The Holocene 24 (4): 381-392. DOI: http:// dx.doi.org/10.1177/0959683613518594

40. WAŻNY T, LORENTZEN B, KÖSE N, AKKEMIK Ü, BOLTRYK $Y$, GÜNER T, KYNCL J, NECHITA C, et al. 2015 Bridging the gaps in tree-ring records: creating a high-resolution dendrochronological network for south eastern Europe. Treering Res 70 (3): 39-50. . DOI: http://dx.doi.org/10.3959/15361098-70.3.39

41. WAZNY T 2009 Is there a separate tree-ring pattern for Mediterranean oak? In: Manning S, Bruce MJ (eds) Treerings, kings, and old world archaeology and environment. Oxbow Books, Oxford, UK, pp 41-50

42. HUGHES M.K, KUNIHOLM PI, GARFIN GM, GRIGGS C, LATINI C 2001 Aegean tree-ring signature years explained. Tree-Ring Res 57 (1): 67-73

43. AKKEMIK U, ARAS 2005 A Reconstruction (1689-1994 AD) of April-August precipitation in the southern part of Central Turkey. Int J Climatol 25 (4): 537-548. DOI: http://dx.doi. org/10.1002/joc.1145

44. AKKEMIK Ü, D'ARRIGO R, CHERUBINI P, KÖSE N, JACOBY GC 2008 Tree-ring reconstructions of precipitation and streamflow for north-western Turkey. Int J Climatol 28 (2): 173-183. DOI: http://dx.doi.org/10.1002/joc.1522

45. TOUCHAN R, XOPLAKI E, FUNKHOUSER G, LUTERBACHER J, HUGHES K, ERKAN N, AKKEMIK U, STEPHAN J 2005 Reconstruction of spring/summer precipitation for the eastern Mediterranean from tree-ring widths and its connection to large-scale atmospheric circulation. Clim Dynam 25 (1): 75-98. DOI: http://dx.doi.org/10.1007/ s00382-005-0016-5

46. TOUCHAN R, AKKEMIK U, HUGHES K, ERKAN N 2007 MayJune precipitation reconstruction of southwestern Anatolia, Turkey, during the last 900 years from tree rings. Quaternary Res 68 (2):196-202. DOI: http://dx.doi.org/10.1016/i. yqres.2007.07.001

47. GRIGGS C, DE GAETANO A, KUNIHOLM P, NEWTON M 2007 $A$ regional high-frequency reconstruction of May-June precipitation in the north Aegean from oak tree-rings, $A D$ 1089-1989. Int J Climatol 27 (8): 1075-1089. DOI: http:// dx.doi.org/10.1002/joc.1459

48. GRIGGS C, PEARSON CH, MANNING SW, LORENTZEN B 2013 A 250-year annual precipitation reconstruction and drought assessment for Cyprus from Pinus brutia Ten. tree-rings. Int J Climatol 34 (8): 2702-2714. DOI: http://dx.doi.org/10.1002/ joc.3869

49. PAPADOPOULOS AM 1996 Dendrochronology Dendroclimatology of coniferous species in Greece. In: Hellenic Forestry Association, Utilization of Forest Resources, Proceedings of 7th Panhellenic Forest Conference, Karditsa, Greece, 11-13 October 1995, pp 625-632 (in Greek) 
50. PAPADOPOULOS A, PANTERA A, GOUDELIS G, RAFTOYANNIS I, STAMATOPOULOS E, VERGOS S 2006 Sensitivity of Aleppo pine tree rings (Pinus halepensis Mill.) in climatic data for the period 1960-2003 in Attica. In: Hellenic Forestry Association, Forest and water - natural environment protection, Proceedings of 12th Panhellenic Forest Conference, Drama, Greece 2-5 October 2005, pp 379-386 (in Greek)

51. FOUNDA D, PAPADOPOULOS KH, PETRAKIS $M$, GIANNAKOPOULOS C, GOOD P 2004 Analysis of mean, maximum, and minimum temperature in Athens from 1897 to 2001 WITH emphasis on the last decade: trends, warm events, and cold events. Global Planet Change 44 (1-4): $27-$ 38. DOI: http://dx.doi.org/10.1016/i.gloplacha.2004.06.003
52. NICAULT A, ALLEAUME S, BREWER S, CARRER M, NOLA P, GUIOT J 2008 Mediterranean drought fluctuation during the last 500 years based on tree-ring data. Clim Dynam 31 (2): 227-245. DOI: http://dx.doi.org/10.1007/s00382-007-0349-3 53. XOPLAKI E, MAHERAS P, LUTERBACHER J 2001 Variability of Climate in Meridional Balkans during the Periods 1675-1715 and 1780-1830 and its Impact on Human Life. Climatic Change 48 (4): 581-615. DOI: http://dx.doi. org/10.1023/A:1005616424463

54. SIAM AMJ, RADOGLOU KM, NOITSAKIS B, SMIRIS P 2009 Differences in ecophysiological responses to summer drought between seedlings of three deciduous oak species. Forest Ecol Manag 258 (1): 35-42. DOI: http://dx.doi.org/10.1016/i. foreco.2009.03.048 
